\title{
Comparison of Employment Impacts of Renewable and Fossil Energy Based Electricity Sectors: The Case of Turkey ${ }^{1}$
}

\author{
Yenilenebilir ve Fosil Enerjiye Dayalı Elektrik Sektörlerinin İstihdam Etkilerinin \\ Karşılaştırılması: Türkiye Örneği
}

\author{
Yahya $A L G \ddot{U} L$ * \\ Vedat $K A Y A^{* *}$
}

\begin{abstract}
Considering rapidly rising air pollution and unemployment problem in Turkey, renewable energy may be the most appropriate solution for both of the problems. While positive effect of renewable energy on the environement is widely acknowledged, there isn't sufficient research about its effect on employment statistics. For this reason, in this study, the net employment benefit of the renewable-based electricity sector, against the fossil-based electricity sector, is investigated through Input-Output methodology. The estimation is done for both manufacturing/installation and operation/maintenance phases of solar, wind, hydropower, bioenergy, geothermal, coal, petrol, and natural gas-based electricity sectors, including all of the direct, indirect, and induced effects. According to the estimation results of both approaches and both of the phases, renewable-based electricity sectors are more effective than fossil-based electricity sectors in terms of employment generation. Therefore, besides its claimed benefits in terms of environment, the renewable energy sector may be a major instrument in the sustainable development efforts in Turkey, considering its employment benefits too.
\end{abstract}

\section{KEYWORDS}

Sustainable Development, Input-Output, Renewable Energy, Green Employment

$\ddot{O} Z$

Türkiye'de hızla artan çevre kirliliği ve işsizlik sorunları göz önüne alındığında, yenilenebilir enerji her iki sorunla eşanlı mücadele bağlamında en uygun çözüm olabilir. Yenilenebilir enerjinin çevre üzerindeki pozitif etkisi noktasında yaygın bir uzlaşı bulunmasına rağmen, istihdam etkisi yeterince araştırılmamıştır. Bu doğrultuda çalışmamızda, yenilenebilir enerjiye dayalı elektrik sektörünün fosil bazlı elektrik sektörüne klyasla net istihdam etkisi Girdi-Çıtı metodolojisi ile incelenmiştir. Analiz, güneş, rüzgar, hidroelektrik, biyoenerji, jeotermal, kömür, petrol ve doğal gaza dayalı elektrik sektörlerinin hem üretim/kurulum hem de işletme/bakım aşamaları için doğrudan, dolaylı ve uyarılmış etkilerinin tümünü içermektedir. Her iki yaklaşımın ve her iki aşamanın tahmin sonuçlarına göre, yenilenebilir enerjiye dayalı elektrik sektörlerinin, istihdam yaratma açısından fosil bazlı elektrik sektörlerine göre daha etkili olabileceği sonucuna varılmıştır. Bu nedenle, yenilenebilir enerji sektörü çevre açısından iddia edilen faydalarının yanı sıra, istihdam faydaları da dikkate alındı̆̆ında Türkiye'deki sürdürülebilir kalkınma çabalarında önemli bir araç olabilir.

\section{ANAHTAR KELIMELER}

Sürdürülebilir Kalkınma, Girdi-Çıktı, Yenilenebilir Enerji, Yeşil İstihdam

\begin{tabular}{|c|c|c|}
\hline \multicolumn{2}{|c|}{ Makale Geliş Tarihi / Submission Date } & \multicolumn{1}{c|}{$\begin{array}{c}\text { Makale Kabul Tarihi / Date of Acceptance } \\
\text { 10.07.2021.09.2021 }\end{array}$} \\
\hline \multirow{3}{*}{ Atıf } & $\begin{array}{l}\text { Algül, Y. ve Kaya, V. (2021). Comparison of Employment Impacts of Renewable and Fossil Energy Based Electricity } \\
\text { Sectors: The Case of Turkey. Selçuk Üniversitesi Sosyal Bilimler Meslek Yüksekokulu Dergisi, 24 (2), 421-439. }\end{array}$ \\
\hline
\end{tabular}

\footnotetext{
${ }^{1}$ This study is based on the $\mathrm{PhD}$ thesis of the first author.

* Asst. Prof., Erzurum Technical University Faculty of Economics and Administrative Sciences, yahya.algul@erzurum.edu.tr, ORCID: 0000-00033480-9871

** Prof., Atatürk University Faculty of Economics and Administrative Sciences, vkaya@atauni.edu.tr, ORCID: 0000-0002-7206-4236
} 


\section{INTRODUCTION}

The World Summit on Sustainable Development held in 2002 underlines three important aspects of Sustainable Development as the environmental, the economic, and the social ones and the economic one refers to sustained economic growth as a necessary condition of social wellbeing and satisfaction of basic human needs, while the social element refers to providing equality both in terms of income, political participation as well as social integration and cohesion of different groups (Rontos et. al., 2015). The environmental element refers to guaranteeing the provisioning capacity of the ecosystem for the current and future generations (Rontos et. al., 2015).

Looking at those three elements one can see that environmental damage and unemployment are two central problems that may threaten all of the central tenets of sustainable development. According to Stern Review (Stern, 2007), global warming as a mostly outcome of rising greenhouse gas emissions through fossil energy consumption will seriously disrupt the basics elements of life and sustainable development. Some of those disruptions are malnutrition due to limited food production, limited access to drinking water, health problems due to a polluted environment, loss of biodiversity, coastal floodings, and a variety of other environmental disasters.

While environmental problems have very long term dynamics and are analyzed from a much longer perspective, unemployment, on the other hand, is a much urgent problem in terms of satisfaction of human needs and sustainable development. It is because the high unemployment rate isn't solely a statistic about macroeconomics, rather it is a much bigger problem that affects the wellbeing of individuals in terms of malnutrition and other related health problems, psychological disorders such as depression and anxiety, alcohol, and drug addiction (Forstater, 1999; Dasgupta and Ray, 1986).

Moreover, the insufficiency of basic human needs due to unemployment reflects its symptoms at the social level through inequality of opportunity in education for current and next generations, domestic violence, terrorist activities, and crime (Vickrey, 1997; Dursun et. al., 2011). Studies investigated the relation between unemployment and crime for the case of Turkey show that unemployment has a significantly negative effect on the crime rates in Turkey (Ata, 2011; Aksu and Akkuş, 2010). Therefore, alleviating unemployment in Turkey may contribute to the social aspect of sustainable development efforts too.

Another important issue in sustainable development related to unemployment is internal migration. According to the 2006 World Bank report, one of the structural reasons for unemployment in Turkey is the internal migration of the agricultural labor force ongoing since the $1950 \mathrm{~s}$, from rural regions to cities in the hope to find a job (Akçoraoğlu, 2010). This type of structural unemployment arises due to a mismatch between the skills of the newly immigrated labor force and industrial requirements. This isn't only an issue for the unemployed, rather it is a broader problem that disrupts social cohesion and causes different types of unrest in society. According to Kar and Comertler(2007), associated with unemployment, internal migration and extreme population density in cities are important components of high crime rates and related social problems.

Besides the social perspective, unemployment is an economic problem of aggregate demand, deficiency of which is one of the most important problems for Keynesian economists. According to this tradition, in times of economic stagnation, waiting for the markets for their self-correction or implying supply-side policies may not be suitable (Bell and Randall, 2004). Rather, employment must be supported by the governments so that with the increasing purchasing power and the multiplier effect economies may recover from deficiency of demand and continue to economic growth and development (Tcherneva, 2008). Otherwise, the cost of waiting for self-correction may be an irreversible loss at employment and GDP.

The general experience shows the significance of high rates of economic growth against the unemployment problem (Islam, 2004). However, growth policies aimed to increase aggregate demand and stimulate employment may result in increased greenhouse gas emissions and environmental damage. This potential tradeoff between environmental policies and employment supportive policies has been an important concern in the literature (Chen, 2019; Moreno and Lopez, 2008; Pollin and Garret-Peltier 2009) Turkish experience, however, has been different. Despite the robust growth performance of the post-1980s period, neither unemployment rates nor pollution statistics have shown a strong downward trend in Turkey. Just the opposite, both unemployment and environmental pollution problems are worsening at the Turkish development experience since the 1980s.

From this perspective, the 1980s are an important turning point for Turkey. Until the 1980s, generally, import substitution policies are implemented in Turkey, but from the 1980s onwards the industrialization strategy has changed towards an export-oriented development regime, , to combine the Turkish economy to the international sphere (Ünal, 2016; Yıldırım and Sezgin, 2003). The argument was the greater liberalization 
of trade would eventually lead to a growth in economy and employment, however, growth in employment rates has never been achieved (Y1ldirım and Sezgin, 2003).

While unemployment has been a chronic problem for the Turkish economy since the 1980s, this problem recently has deepened even more. In May 2020 unemployment rate in Turkey was 12,9\% (Turkstat, 2020a), after 2019's highest rate of 14,7\% (Turkstat, 2019a). Moreover, the youth unemployment rate in May 2020 was 24,9\% (Turkstat, 2020a), after the 2019 record high of 26,1\% (Turkstat, 2019a). Another important statistic about unemployment is those relatively high records occur despite Turkey's relatively low labor force labor participation rates. At 2019 labor force participation rate in Turkey stood at 62,3\% while that rate was 80,3\% in E.U. countries (OECD, 2019).

Moreover, beyond the rising unemployment problem, the current account deficit is another problem in Turkey. To keep economic growth sustainable in the Turkish economy, it is essential to have a healthy current account balance. But, Turkish growth periods are correlated with rising current account deficits, since imports in Turkey arise faster than exports when the economy is prospering (Ercan, 2007). Since the liberalization of the economy in the 1980s the current account deficit has a persistent structure in Turkey due to the saving gap and reliance on foreign sources in intermediate goods and energy (Özata, 2014).

An important part of that current account deficit in Turkey is the trade deficit that arises through fossil energy import. In 2019 the Turkish trade deficit has been 31,1 billion dollars (Turkstat, 2019b), comparing to the 41,1 billion dollars of fossil energy import at the same period (AA, 2019). Thus lowering the fossil energy import may increase Turkey's energy independence and minimize the trade deficit which subsequently feeds Turkey's persistent financial fragility, financial crisis, and unemployment problems.

Furthermore, due to rapid economic growth applied trough energy-intensive obsolete industries and imported fossil fuel environmental pollution, especially air pollution, intensifies in Turkey too. According to the World Bank (2019) per capita, $\mathrm{CO}_{2}$ emission in Turkey raised more than seven-folds, from 0,61 tonnes in 1960 to 4,48 tonnes in 2014.

Accordingly, rich domestic renewable energy resources may help to both reduce the current account deficit and stress on the environment due to fossil energy consumption in Turkey. Therefore a well-planned renewable energy-based development strategy in Turkey may mitigate both environmental pollution, unemployment problem, and other socioeconomic problems at the same time. Consequently, any well-grounded analysis of the sustainable development for the case of Turkey must address the triple problem of environmental degradation, unemployment, and other socioeconomic problems. In this perspective abundant renewable energy resources, she has maybe a strong cure to this triple problem of Turkey.

While renewable energy has a wide variety of benefits, its employment effect compared to the fossil energy sector is still, however, doubtful (Cameron and Zwaan, 2015). It is because although renewable energy may create new jobs at the microeconomic level, at the macroeconomic level there may be employment loss or gain during the transition period from the fossil energy-based organization to a renewable energy-based organization due to structural and intra-industrial differences among the sectors.

In this perspective, this study aims to estimate net job change in Turkey, due to transitioning the electricity sector from the fossil energy-based structure to renewable energy-based structure. Therefore, the objective of this study is to estimate the net job change due to this transitioning period through the input-output methodology. The input-output method is a useful tool to estimate net employment change, but the insufficiency of the level of industrial disaggregation in the input-output tables limits its use. Since renewable energy is not included as a isolated sector in the Turkish input-output tables, the employment potential of the renewable energy sector cannot be analyzed by conventional input-output methods. In this study, this problem is addressed with the final demand and complete inclusion methods. In this way, the employment potentials of renewable and fossil energy-based electricity sectors are examined both for manufacturing/installation and operation/maintenance phases.

The paper is structured as follows. In section 2 the existing literature about the employment impact of the energy sector is reviewed. Section 3 explains the two different methodologies and basic assumptions employed in this study together with the datasets used. Section 4 presents a summary of the extensive results and discusses the sensitivity of results by comparing the two different approaches employed. Moreover, to doublecheck the sensitivity of results, the findings are compared to the results of other studies in the literature too. Finally, section 5 provides the main conclusions of the study.

\section{LITERATURE REVIEW}

With technological advancement, the efficiency of renewable energy technologies has been increasing day by day, which causes both costs to drop and the profitability of the sectors to rise significantly. (REN21, 2019) 
In light of these developments, initial studies by the public institutions, industry associations, and nongovernmental organizations about renewable energy aimed to raise awareness about the potential advantages of renewable energy over the fossil energy sector. Besides the environmental benefits of renewable energy sectors, initial studies intended to underline the potential employment boosting effect of the sector and attracting the public attention (Kammen, et. al.,2004).

In the last decade, however, the number of peer-reviewed academic studies has been increased rapidly. The types of employment that arise due to new spending are analyzed under three separate headings as, direct, indirect, and induced employment effects. Direct employment effect is the reaction of a given industry given a change in final demand for that specific industry, while indirect employment effect displays the reaction by entire supplying industries from a change in final demand for that specific industry (Henriques et al., 2016). On the other hand, for a particular industry, induced employment effect displays the reaction of the entire industries induced by diminished (expanded) spending of new household's income and inter-industrial transfers lost (created) from the direct and indirect employment effects of the variation in final demand (Henriques et al., 2016).

In general, two different approaches are used to estimate those employment effects in the energy sector. These are the employment factor approaches and input-output based models. Apart from these models, in some studies (Liera et al., 2013; Erdal, 2012; Hillebrand, 2006) different methodologies are employed such as supply chain analysis and surveys. The employment factor approach is the most widely used method in the literature since it can be used without detailed data and expertise. Studies based on the employment factor approaches, however, have a clear lack of authenticity in the results, since those studies by repetitively referencing to other studies disregard the country-specific features and differences (Cameron and Zwaan, 2015). This situation causes inflation of non-authentic studies of the employment factor approach in the literature.

Most of those studies come up with positive employment impact conclusion, although some studies (Böhringer et al., 2013; Cai et al., 2011; Wang et al., 2013; Cai et al., 2014; Sooriyaarachchi et al., 2015; Henriques et al., 2016; Behrens et al., 2016) claim neutral, mixed or even negative employment effect. However, with this method, only direct, and with some weak assumptions, indirect employment figures can be estimated (Mu et al., 2018).

Another important issue in the literature is the negligence of the distinction between the first phase of investment that includes the manufacturing and installation and the second phase of investment that includes operation and maintenance. Those two phases have different spending patterns, employment duration, and characteristics that must be considered separately. In the first phase, in general, employment opportunities are richer than the second phase but the duration of employment opportunities is longer in the second phase. Some studies that considered those two phases separately are Moreno and Lopez (2008), Markaki et al., (2013), Simas and Pacca (2014), and Henriques et al., (2016).

In the literature, a great number of studies investigate only the renewable energy sector in terms of employment and only a few studies (Garret-Peltier, 2017; Tourkolias et al., 2009) take into account the conventional fossil-based energy sector. This makes it very difficult to compare the employment effect of different energy technologies vis-à-vis (Cameron and Zwaan, 2015). Since this study includes petroleum, coal, and natural gas-based thermal power plants as well as, hydraulic, geothermal, wind, solar, and biofuel based power plants' employment generation estimations and comparisons of them, it covers an important gap in the literature.

Because of the different methodologies, scopes, and, datasets used to estimate different employment effects for a variety of different energy sectors, employment estimations vary widely in the literature. For this reason, testing the robustness of the estimations by comparing the estimations with other studies' estimations is important, however, in the literature, only one study intended to do that briefly for the Portuguese and Tunisian case (Cameron and Zwaan, 2015). Although in this study two different methodological approaches are used to test the sensitivity of the results, in the results and discussion section estimations found are compared for other countries' estimations to double-check the sensitivity.

An additional intriguing point in the literature is the concentration of studies on European and other developed countries cases which shows an important gap in the literature and the need for more evidence from developing countries too (Wei, et. al, 2010; Simas and Pacca, 2014). In the case of Turkey, studies were either employed weak methodologies, datasets, or both of them. For example, Çetin and Eğrican(2011) for each MWp installed capacity of solar energy systems assumed 37 to 46 direct employment in Turkey without any clear estimation or referencing to their assumption. Then by assuming multiplier effect two, one more time without any estimation or referencing, for each direct employment one indirect employment assumed. 
Another study (Erdal, 2012) conducted only a telephone survey for a few operating renewable energy firms in Turkey to keep the statistics of employment without any estimation of employment at the manufacturing and installation phase and without any estimation of indirect and induced employment effects. The other two studies (Erdoğdu and Karaca, 2016; Karaca et. al, 2017) for the Turkish case used a computer application that prepared for the U.S.A. with an American input-output dataset and employment multipliers for estimation.

Therefore, even though, the vast majority of results show growth in the renewable energy sector has a positive impact on employment, this may be due to a specific economic structure of developed countries. Moreover, while project-based microeconomic data collected from developed countries may be partially useful for feasibility studies of developing countries' firms to estimate potential expenditures and employment needs of local projects, it may not be suitable for the macroeconomic planning needs. Since neglecting the differences in capital intensity, technological advancement, labor productivity, wage, renewable energy potential, and other differences across countries may cause biased estimations. A summary of studies in the literature can be seen in table 1. 
Table 1 Summary of the literature

\begin{tabular}{|c|c|c|c|c|c|c|c|c|c|c|}
\hline \multirow{2}{*}{ Study } & \multirow{2}{*}{ Region } & \multirow{2}{*}{ Methodology } & \multirow{2}{*}{ Sector } & \multirow{2}{*}{$1^{\text {st }}$ Phase } & \multirow{2}{*}{$2^{\text {nd }}$ Phase } & \multicolumn{3}{|c|}{ Direc Indire Induc } & \multirow{2}{*}{ Brut } & \multirow{2}{*}{ Net } \\
\hline & & & & & & $t$ & $c t$ & $e d$ & & \\
\hline 1)Çetin \& Eğrican (2011) & Turkey & F.M. & S & $14.59 \mathrm{P} /$ & MTL & $\mathrm{x}$ & $\mathrm{x}$ & & $\mathrm{x}$ & \\
\hline 2)Erdal (2012) & Turkey & Survey & $\mathrm{W}, \mathrm{G}$ & & $\mathrm{x}$ & $\mathrm{x}$ & & & $\mathrm{x}$ & \\
\hline 3)Karaca, et. al. (2017) & Turkey & F.M. & All & $\mathrm{x}$ & $\mathrm{x}$ & $\mathrm{x}$ & $\mathrm{x}$ & $\mathrm{x}$ & $\mathrm{x}$ & \\
\hline 4)Erdoğdu \& Karaca (2016) & Turkey & Comp. App. & $S$ & $23.42 \mathrm{P} / \mathrm{MW}$ & $1,16 \mathrm{P} / \mathrm{MW}$ & & & & & \\
\hline 5)Singh \& Fehrs (2001) & U.S.A. & Survey & $\mathrm{W}, \mathrm{S}, \mathrm{B}$ & 3.8-35.5 P/MW & & $\mathrm{x}$ & & & $\mathrm{x}$ & \\
\hline 6)Kammen et.al. (2004) & U.S.A. & Lit. Sum. & All & $\mathrm{x}$ & $\mathrm{x}$ & $\mathrm{x}$ & $\mathrm{x}$ & $\mathrm{x}$ & $\mathrm{x}$ & $\mathrm{x}$ \\
\hline 7)Moreno, Lopez (2008) & Asturias & F.M. & All & 0.12-34.6 P/MW & $0.01-6 \mathrm{P} / \mathrm{MW}$ & $\mathrm{x}$ & & & $\mathrm{x}$ & \\
\hline 8)Wei \& Kammen (2010) & A.B.D. & F.M. & All & $\mathrm{x}$ & $\mathrm{x}$ & $\mathrm{x}$ & $\mathrm{x}$ & $\mathrm{x}$ & $\mathrm{x}$ & $\mathrm{x}$ \\
\hline 9)Garret-Peltier (2017) & A.B.D. & $\mathrm{I}-\mathrm{O}$ & All & 7.2-7.6 P/MUSD & & $\mathrm{x}$ & $\mathrm{x}$ & & $\mathrm{x}$ & $\mathrm{x}$ \\
\hline 10)Lehr et.al. (2016) & Tunisia & $\mathrm{I}-\mathrm{O}$ & - & $\mathrm{x}$ & & $\mathrm{x}$ & $\mathrm{x}$ & & $\mathrm{x}$ & \\
\hline 11)Henriques et.al. (2016) & Portugal & $\mathrm{I}-\mathrm{O}$. & All & 5.0-25.1 P/MW & 0.05-0.41 P/MW & $\mathrm{x}$ & $\mathrm{x}$ & $\mathrm{x}$ & $\mathrm{x}$ & $\mathrm{x}$ \\
\hline 12)Cai et.al. (2011) & China & I-O F.M. & All & $0.4-3,27 \mathrm{P} / \mathrm{MWh}$ & & $\mathrm{x}$ & $\mathrm{x}$ & & $\mathrm{x}$ & $\mathrm{x}$ \\
\hline 13)Oliveira et.al. (2014) & U.K. & $\mathrm{I}-\mathrm{O}$ & All & $\mathrm{x}$ & $\mathrm{x}$ & $\mathrm{x}$ & $\mathrm{x}$ & $\mathrm{x}$ & $\mathrm{x}$ & \\
\hline 14)Markaki et.al. (2013) & Greece & $\mathrm{I}-\mathrm{O}$ & All & 17,6-20,8 P/MUSD & 17-20 P/MUSD & $\mathrm{x}$ & $\mathrm{x}$ & $\mathrm{x}$ & $\mathrm{x}$ & \\
\hline 15)Schwartz et.al. (2009) & L.America & F.M. & $\mathrm{S}, \mathrm{W}, \mathrm{B}$ & $\mathrm{x}$ & & $\mathrm{x}$ & $\mathrm{x}$ & $\mathrm{x}$ & $\mathrm{x}$ & $\mathrm{x}$ \\
\hline 16)Böhringer et.al. (2013) & Germany & I-O-C.G.E & Mixed & $\mathrm{x}$ & & $\mathrm{x}$ & $\mathrm{x}$ & $\mathrm{x}$ & $\mathrm{x}$ & $\mathrm{x}$ \\
\hline 17)LIera et.al. (2013) & Spain & V.Chain & $\mathrm{S}$ & $\mathrm{x}$ & $\mathrm{x}$ & $\mathrm{x}$ & $\mathrm{x}$ & & $\mathrm{x}$ & \\
\hline 18)Simas \& Pacca (2014) & Brazil & $\mathrm{I}-\mathrm{O}$ & $\mathrm{W}$ & 13.5 P/MW & $0,59 \mathrm{P} / \mathrm{MW}$ & $\mathrm{x}$ & $\mathrm{x}$ & & $\mathrm{x}$ & \\
\hline 19)Lehr et.al.(2012) & Germany & I-O/P.R. & Mixed & $\mathrm{x}$ & $\mathrm{x}$ & $\mathrm{x}$ & $\mathrm{x}$ & & $\mathrm{x}$ & $\mathrm{x}$ \\
\hline 20)Tourkolias\&Mirasgedis(2011) & Greece & $\mathrm{I}-\mathrm{O}$ & All & 17.2-46.9 P/MW & 8.4-135 P/MW & $\mathrm{x}$ & $\mathrm{x}$ & $\mathrm{x}$ & $\mathrm{x}$ & \\
\hline 21)Mu, et.al. (2018) & China & I-O-CGE & $S, W$ & $0.012-0.042 \mathrm{~K} / \mathrm{MW}$ & 0.003-0.002 P/MW & $\mathrm{x}$ & $\mathrm{x}$ & $\mathrm{x}$ & $\mathrm{x}$ & $\mathrm{x}$ \\
\hline 22)Neuwahl et.al. (2008) & E.U. & $\mathrm{I}-\mathrm{O}$ & B & $\mathrm{x}$ & & $\mathrm{x}$ & $\mathrm{x}$ & $\mathrm{x}$ & $\mathrm{x}$ & $\mathrm{x}$ \\
\hline 23)Markandya et.al. (2016) & E.U. & I-O- M.R. & Mixed & $\mathrm{x}$ & & $\mathrm{x}$ & $\mathrm{x}$ & & $\mathrm{x}$ & \\
\hline 24)Lund \& Hvelplund (2012) & Denmark & $\mathrm{I}-\mathrm{O}$ & $\mathrm{S}, \mathrm{G}, \mathrm{B}$ & $\mathrm{x}$ & $\mathrm{x}$ & $\mathrm{x}$ & $\mathrm{x}$ & & $\mathrm{x}$ & \\
\hline 25)Hillebrand et.al. (2006) & Germany & I-O-S.M. & All & $\mathrm{x}$ & & $\mathrm{x}$ & $\mathrm{x}$ & $\mathrm{x}$ & & $\mathrm{x}$ \\
\hline 26)Heindl \& Voigt (2012) & Germany & $\mathrm{I}-\mathrm{O}$ & All & $\mathrm{x}$ & $\mathrm{x}$ & $\mathrm{x}$ & $\mathrm{x}$ & $\mathrm{x}$ & $\mathrm{x}$ & $\mathrm{x}$ \\
\hline 27)Chateau \& Martin(2013) & OECD & I-O-CGE & All & $\mathrm{x}$ & & $\mathrm{x}$ & $\mathrm{x}$ & $\mathrm{x}$ & & $\mathrm{x}$ \\
\hline 28)Cai, et.al. (2014) & China & $\mathrm{I}-\mathrm{O}$ & All & $\mathrm{x}$ & & $\mathrm{x}$ & $\mathrm{x}$ & & $\mathrm{x}$ & $\mathrm{x}$ \\
\hline 29)Blazejczak et.al. (2014) & Germany & I.O-SEEEM & All & $\mathrm{x}$ & $\mathrm{x}$ & $\mathrm{x}$ & $\mathrm{x}$ & $\mathrm{x}$ & & $\mathrm{x}$ \\
\hline 30)Sooriyaarachchi, et.al. (2015) & S.Count. & F.M. & Mixed & $\mathrm{x}$ & $\mathrm{x}$ & $\mathrm{x}$ & $\mathrm{x}$ & $\mathrm{x}$ & $\mathrm{x}$ & $\mathrm{x}$ \\
\hline 31)Ortega, et.al.(2015) & E.U. & F.M. & S, W & $\mathrm{x}$ & $\mathrm{x}$ & $\mathrm{x}$ & $\mathrm{x}$ & & $\mathrm{x}$ & \\
\hline 32)Lübbers, et.al.(2016) & Germany & $\mathrm{I}-\mathrm{O}$ & B & $\mathrm{x}$ & $\mathrm{x}$ & $\mathrm{x}$ & $\mathrm{x}$ & & $\mathrm{x}$ & \\
\hline 33)Behrens, et.al.(2016) & Portugal & $\mathrm{I}-\mathrm{O}$ & Mixed & 1.15 P/MW & $\mathrm{x}$ & $\mathrm{x}$ & $\mathrm{x}$ & & $\mathrm{x}$ & $\mathrm{x}$ \\
\hline 34)Wang, et.al.(2013) & China & $\mathrm{I}-\mathrm{O}$ & All & 378-3222 P/GW & 9.6-104.4 P/GWh & $\mathrm{x}$ & $\mathrm{x}$ & & $\mathrm{x}$ & $\mathrm{x}$ \\
\hline 35)Zwaan, et.al. (2013) & M. East & F.M. & $\mathrm{W}, \mathrm{S}$ & 2.6-43 P/MW & 0.1-1 P./MW & $\mathrm{x}$ & $\mathrm{x}$ & & $\mathrm{x}$ & \\
\hline 36)Oliveira, et.al.(2013) & Portual & I.O-MOLP & All & $\mathrm{x}$ & $\mathrm{x}$ & $\mathrm{x}$ & $\mathrm{x}$ & & $\mathrm{x}$ & \\
\hline 37)Caldes, et.al.(2009) & Spain & $\mathrm{I}-\mathrm{O}$ & $S$ & $\mathrm{x}$ & $\mathrm{x}$ & $\mathrm{x}$ & $\mathrm{x}$ & & $\mathrm{x}$ & \\
\hline 38)Cansino, et.al.(2014) & Andalus. & I-O.-CGE & $S$ & $640 \mathrm{P} / \mathrm{MW}$ & & $\mathrm{x}$ & $\mathrm{x}$ & & $\mathrm{x}$ & \\
\hline 39)Dvorak, et.al.(2017) & Czechia & F.M. & All & $0.7-25 \mathrm{P} / \mathrm{MW}$ & & $\mathrm{x}$ & $\mathrm{x}$ & & $\mathrm{x}$ & \\
\hline 40)Mills (2016) & Africa & F.M. & $S$ & 38P./10000G.E.K. & & $\mathrm{x}$ & & & $\mathrm{x}$ & $\mathrm{x}$ \\
\hline 41)Rodriguez-Huerta, et.al.(2017) & Catalonia & F.M. & All & $\mathrm{x}$ & & $\mathrm{x}$ & $\mathrm{x}$ & & $\mathrm{x}$ & \\
\hline 42)Kis, et.al.(2018) & - & F.M. & All & & 17-94 P/PJ & $\mathrm{x}$ & & & $\mathrm{x}$ & \\
\hline 43)Bulavskaya \& Reynes(2018) & Holland & I-O -CGE & All & $\mathrm{x}$ & & $\mathrm{x}$ & $\mathrm{x}$ & $\mathrm{x}$ & $\mathrm{x}$ & $\mathrm{x}$ \\
\hline 44)Kahouli \& Martin(2018) & France & $\mathrm{I}-\mathrm{O}$ & $\mathrm{W}$ & $6.03 \mathrm{P} / \mathrm{MW}$ & $1.02 \mathrm{P} / \mathrm{MW}$ & $\mathrm{x}$ & $\mathrm{x}$ & $\mathrm{x}$ & $\mathrm{x}$ & \\
\hline 45)Chen, (2019) & China & $\mathrm{I}-\mathrm{O}$ & $\mathrm{S}, \mathrm{W}, \mathrm{B}$ & 100-286 P/MUSD & & $\mathrm{x}$ & $\mathrm{x}$ & & $\mathrm{x}$ & $\mathrm{x}$ \\
\hline 46)Cantore et.al.(2017) & Africa & F.M. & All & $\mathrm{x}$ & & $\mathrm{x}$ & $\mathrm{x}$ & & $\mathrm{x}$ & \\
\hline 47)Bohlmann et.al.(2019) & S.Africa & I.O- CGE & Mixed & $\mathrm{x}$ & & $\mathrm{x}$ & $\mathrm{x}$ & $\mathrm{x}$ & $\mathrm{x}$ & $\mathrm{x}$ \\
\hline 48)Fanning et.al.(2014) & Wales & $\mathrm{I}-\mathrm{O}$ & Wave & 22.9-35.3 P/MW & $0.02-0.8 \mathrm{P} / \mathrm{MW}$ & $\mathrm{x}$ & $\mathrm{x}$ & $\mathrm{x}$ & $\mathrm{x}$ & \\
\hline 49)Matumoto \& Hondo(2011) & Japan & $\mathrm{I}-\mathrm{O}$ & $\mathrm{S}, \mathrm{W}$ & 0,69-2.8 P/GWh & & $\mathrm{x}$ & $\mathrm{x}$ & & $\mathrm{x}$ & \\
\hline $\begin{array}{l}\text { 50)Pollin \& Garrett-Garret-Peltier } \\
\text { (2009) }\end{array}$ & r Ontario & $\mathrm{I}-\mathrm{O}$ & $\mathrm{S}, \mathrm{W}, \mathrm{B}, \mathrm{H}$ & 14,2-16,4 P/MUSD & & $\mathrm{x}$ & $\mathrm{x}$ & & $\mathrm{x}$ & \\
\hline
\end{tabular}


To sum up, most of those studies in the literature are non-authentic and based on the employment factor approach that does not cover all of the direct, indirect, and induced effects. Also, studies rarely consider the manufacturing and installation phase separately from the operation and maintenance phase. Furthermore, to be able to claim that renewable energy is more employment friendly than conventional energy sectors, fossil energy sectors must be compared vis-à-vis to renewable energy sectors which are done very rarely.

In this study by implying two different input-output methodologies based on Turkish input-output tables, renewable-based electricity sectors, and fossil-based electricity sectors are compared for three different employment effects for Turkey. Moreover, this is done for each of the two investment phases and for the eight different subsectors of electricity.

\section{METHODOLOGY AND DATA}

During the usual business operations of the modern capitalist era, which is getting more complex day by day, some companies produce basic and intermediate goods from raw materials while others produce the goods for the final consumption using those basic and intermediate goods. Within this dynamic structure, companies operating in every single field of the economy operate both as producer and consumer of the basic and intermediate goods. The input-output model is one of the most important economic tools for collectively analyzing these two-legged economic flows that occur during the production and consumption of crossindustry products and services.

From this perspective, input-output methods can be used in a wide range of fields with the help of inputoutput tables and other complementary datasets. Economic planning is one of the most common of those. With input-output methodology besides basic and intermediate goods, other factors of production such as the amount of labor to be used directly and indirectly can be predicted and planned too, for the targeted amount of final demand. The input-output methodology is designed to model the entire economy as an interdependence of products and services among numerous sectors and consumers, so that, by supplying the most complete picture of the system as a whole, it takes the snapshot of the economy (Wei et. al, 2010). It captures employment multiplier effects, as well as the macroeconomic outcome of switching among sectors, in another word, it accounts for losses in one sector (e.g. thermal power plants) initiated by the development of another sector (e.g. the solar energy) (Wei et. al, 2010).

The building of an input-output table is an extremely complicated and time-consuming operation, since collecting and arranging a tremendous volume of quantitative data causes an indispensable delay for the publication; accordingly, input-output tables are always historical documents in nature (Leontief, 1986). This limitation applies to our study and all other input-output based studies too. The latest input-output table prepared by the Turkish Statistical Institute for Turkey and used in our study covers the year 2012 and was only released at the end of December 2016 (Turkstat, 2016). Therefore, implications derived from input-output models should be assessed with precaution in the long term analysis.

Another important difficulty tied to input-output tables is the insufficiency of sectoral disaggregation at the national accounts. The Turkish input-output table is disaggregated as 64 industries and 64 products as per the European Union standardization (Turkstat, 2016). In those 64 industries, there isn't any explicit category for renewable energy sectors. All kinds of electricity technologies were consolidated into the electricity sector and the electricity sector is further consolidated into the "Electricity, gas, steam and air conditioning" sector. Therefore there is no chance to readily compare the different technologies in the electricity sector. However, even though, there isn't any explicit renewable energy-based electricity sector or even an electricity sector, those sectors are implicitly embedded in the "Electricity, gas, steam and air conditioning" sector.

To resolve this problem one may take spending in the energy sector as a demand shock as explained by Miller and Blair (2009). By creating a proxy demand vector that constitutes the manufacturing, construction, installation, and other costs of the sector and simulating the new investment in that sector, change in the number of jobs can be estimated (Garret-Peltier, 2017). The second method to overcome the insufficiency of data at input-output tables would be rearranging the already existing sectors and creating new sectors by separating them from other sectors as it explained again by Miller and Blair(2009) and implemented by GarretPeltier(2017). In this study, we have used both of those approaches for the case of Turkey.

\subsection{Final Demand Approach}

Although the renewable energy sector is not considered as an independent industry in input-output tables, the outcomes of investment in the sectors could be estimated by utilizing the cost structure of the sector that derives from the production technic, and with this approach, the actual data in the national accounts and inputoutput tables can be utilized for a particular industry (Miller and Blair, 2009). 
For example, "solar" or "geothermal" sectors are not distinguished as industries, rather services and other inputs making up the solar and geothermal sectors are implicitly included in input-output tables. To be able to abstract this information from existing tables, a proxy vector of demand that captures package of goods and services making up each industry is created, then additional spending treated as investments in these industries so that consequences of enlarging the renewable energy sector can be simulated (Garret-Peltier, 2017). If, for example, a vector of manufacturing and installation requirements of the solar energy sector from various other sectors and their weight in total expenditures obtained, the effect of stimulation in the solar energy sector can be estimated by this proxy demand vector.

The first step in this approach is finding the Leontief Inverse Matrix (I-A) ${ }^{-1}$ with the help of the Turkish Input-output table released in December 2016 (Turkstat, 2016), and the MATLAB software. Then at the second stage, by post multiplying Leontief Inverse Matrix with the proxy demand vector(PDV) the change in the gross output $(\Delta \mathrm{X})$ containing the direct and indirect effects can be estimated. In the Matrices form the basic equitation is

$$
\Delta \mathrm{X}=(\mathrm{I}-\mathrm{A})^{-1} \mathrm{x} \Delta \mathrm{PDV}
$$

Here PDV data reflect different cost structures of a variety of electricity sectors. PDV data for the manufacturing and installation phase is driven from data supplied by Garret-Peltier(2017) and data for the operation and maintenance phase is driven from the study of Tourkolias and Mirasgedis(2011) together with data supplied by American National Renewable Energy Laboratory (Nrel, 2018). When multiple datasets are available for any sector, arithmetic means are used.

The total changes in the gross output triggered by new investments in the electricity sectors trough proxy demand vectors are found. But, rather than the change in the gross output, to find the change in employment, Employment Requirement Matrix(ERM) is needed. The ERM matrix shows the total change in employment associated with a change at the gross output. The equation for ERM is as follows;

ERM: (E/O).(I-A) $)^{-1}$

(E/O) matrix is formed by total employment/total output ratios at diagonal cells and zeros at other cells for each industry. The total number of employment for each industry is acquired from the Household Labor Force Survey (Turkstat, 2012a). By post multiplying the (E/O) matrix with Leontief Inverse Matrix, the ERM matrix is acquired.

ERM matrix shows the number of jobs created throughout the production circle. Each diagonal cell shows the number of jobs necessary for every single industry in the system to meet a million dollars of final demand for a given sector. Multiplying a given row of the employment requirements table by the vector of final demand shows the volume of jobs produced within the sector (Byun, 2010). Here multiplying proxy demand vector(PDV) with ERM gives the employment created both directly and indirectly at all sectors $(\mathrm{E})$ as shown in the following equation.

$\Delta \mathrm{E}=\mathrm{ERM} . \Delta \mathrm{PDV}$

Up until now, the methodology shown is aimed to estimate the direct and indirect employment changes due to growth in the subsectors of the electricity industry, for both manufacturing/installation and operation/maintenance phases. Besides the direct and indirect effect, to estimate the induced effect, which is the outcome of changing household income, the household sector needs to be endogenized.

This requires the household sector to be added to the input-output table as an additional row and column which leads to a closed version of the input-output table, so that compensation of employees and household expenditures are integrated to the modeling (Henriques, et. al., 2016). Therefore, the household sector counted both as producer and consumer in the input-output modeling. With the newly updated input-output table, we apply the procedure already explained for both manufacturing/installation and operation/maintenance phases.

\subsection{Complete Inclusion Approach}

The findings reached through the final demand model may reflect some of the economic relations due to the nature of the methodology applied. As Miller and Blair(2009) explained; a new branch of economic activity within the economic structure not only demands input from other industries but also it will supply its products and services to other sectors. Consequently, the macroeconomic production structure will inevitably change completely. First of all, there will be a new column and row of input coefficients related to purchases by and sales of the new sector. Moreover, there might be changes in the A matrix, reflecting, for instance, the substitution of the newly available input for the one previously used (Miller and Blair, 2009).

In this respect, our study is taken a step further and the complete inclusion approach explained by Miller and Blair (2009) is implemented as a second model. With this methodology, the already existing 64x64 inputoutput table expanded by adding extra new rows and columns associated with different electricity sectors, so 
that a more detailed and disaggregated data set can be obtained. Although the total volume of economic activity does not change with the new data set, different electricity technologies, which all of them previously aggregated into the "Electricity, gas, steam and air conditioning" sector, can be analyzed in more detail.

Once again the input-output table released in December 2016 by Turkstat(2016) is used as the main data. As mentioned earlier, leaving aside the renewable energy-based electricity sectors, even the electricity sector is not taken as an independent industry in the Turkish input-output table. Therefore the first step is disassociating the electricity sector from the "Electricity, gas, steam and air conditioning" sector.

Due to the privatization of different branches of the electricity sector in the different regions of Turkey and a variety of tariffs applied by that privatized firms, the total financial size of the electricity sector couldn't be found readily. To estimate the financial magnitude of the sector, the total volume of electricity consumption data (Turkstat, 2012b) and the average unit price of electricity data (Turkstat, 2012c) both for the residential and industrial consumer are used.

With this calculation, the Turkish electricity sector is estimated to size up to 53.892.199.185 TL out of 122.290.921.000 TL sized "Electricity, gas, steam and air conditioning" sector. Therefore the electricity sector (ES) multiplier and remaining sector of "gas, steam and air conditioning"(RS) multiplier is found to be 0.440688 and 0.559311 respectively.

In the first step using those multipliers, $\mathrm{w}_{1}$ and $\mathrm{w}_{2}$, the input-output table is extended from $64 \times 64$ to the size of $65 \times 65$. The separation scheme of those two sectors is seen in table 2 . Then at the following step electricity sector is further disaggregated into eight new subsectors similar to the one implemented in table 2 , with a more complex disaggregation process. This disaggregation is based on the market share of different electricity sectors acquired from energy balance tables (Eigm, 2012).

Table 2 Two Sector Disaggregation Scheme

\begin{tabular}{|c|c|c|c|c|c|c|}
\hline & Sector A & Sector B & Sector C & $\begin{array}{l}\text { Electricity } \\
\text { Sector(ES) }\end{array}$ & $\begin{array}{l}\text { Remaining } \\
\text { Sector(RS) }\end{array}$ & Sector ... \\
\hline Sector A & $\mathrm{A}_{\mathrm{aa}}$ & $\mathrm{A}_{\mathrm{ab}}$ & $\mathrm{A}_{\mathrm{ac}}$ & $\begin{array}{c}A_{a E S}= \\
A_{a E S} X w_{1} \\
A_{b E S}=\end{array}$ & $\begin{array}{c}\mathrm{A}_{\mathrm{aRS}}= \\
\mathrm{Aa}_{\mathrm{ES}} \mathrm{X} \mathrm{w}_{2}\end{array}$ & $\mathrm{~A}_{\mathrm{a} . .}$ \\
\hline Sector B & $\mathrm{A}_{\mathrm{ba}}$ & $A_{b b}$ & $A_{b c}$ & $\begin{array}{c}\mathrm{A}_{\mathrm{bES}}= \\
\mathrm{A}_{\mathrm{bES}} \mathrm{X} \mathrm{w}_{1}\end{array}$ & $\begin{array}{c}A_{b R S}= \\
A_{b E S} \times w_{2}\end{array}$ & $A_{b .}$ \\
\hline Sector C & $\mathrm{A}_{\ldots \mathrm{a}}$ & $\mathrm{A}_{. . \mathrm{b}}$ & $\mathrm{A}_{\mathrm{cc}}$ & $\begin{array}{c}\mathrm{A}_{. . \mathrm{ES}}= \\
\mathrm{A}_{\text {..ES X W }}\end{array}$ & $\begin{array}{c}\mathrm{A}_{. . \mathrm{RS}}= \\
\text { A.. Electr. } \mathrm{X} \mathrm{W}_{2}\end{array}$ & A... \\
\hline $\begin{array}{c}\text { Electricity } \\
\text { Sector }\end{array}$ & $\begin{array}{c}\mathrm{A}_{\mathrm{FEa}}= \\
\mathrm{A}_{\text {Electr. a }} \mathrm{X} \mathrm{W}_{1}\end{array}$ & $\begin{array}{c}\mathrm{A}_{\mathrm{FEb}}= \\
\mathrm{A}_{\text {Electr.b }} \mathrm{X} \mathrm{W}_{1}\end{array}$ & $\begin{array}{c}\mathrm{A}_{\mathrm{FE} . .}= \\
\mathrm{A}_{\text {Electr. .. X W }}\end{array}$ & $\begin{array}{c}\mathrm{A}_{\mathrm{FE} \mathrm{FE}}= \\
\mathrm{A}_{\text {Electr. Electr. } \mathrm{X}} \\
\mathrm{W}_{1} \mathrm{X} \mathrm{w}_{2}\end{array}$ & $\begin{array}{c}\mathrm{A}_{\mathrm{FE} \mathrm{YE}}= \\
\mathrm{A}_{\text {Electr. Electr. } \mathrm{X}} \\
\mathrm{W}_{2} \mathrm{X} \mathrm{\textrm {W } _ { 1 }}\end{array}$ & $\begin{array}{c}\mathrm{A}_{\mathrm{FE} . .}= \\
\mathrm{A}_{\text {Electr. }} \mathrm{X} \mathrm{W}_{1}\end{array}$ \\
\hline $\begin{array}{l}\text { Remaining } \\
\text { Sector }\end{array}$ & $\begin{array}{c}\mathrm{A}_{\text {YE a }}= \\
\text { AElectr. a X W2 }\end{array}$ & $\begin{array}{c}A_{Y E b}= \\
A_{E l e c t r . b} \mathrm{X} \mathrm{W} \mathrm{W}_{2}\end{array}$ & $\begin{array}{c}\mathrm{A}_{\text {YE.. }}= \\
\mathrm{A}_{\text {Electr... X W }}\end{array}$ & $\begin{array}{c}\mathrm{A}_{\text {YE FE }}= \\
\text { A Electr.Electr. X } \\
\mathrm{W}_{1} \mathrm{X} \mathrm{W}_{2}\end{array}$ & $\begin{array}{c}\text { AYE FE }_{\text {Y }}= \\
\text { AElectr.Electr. X } \\
\mathrm{W}_{2} \mathrm{X} \mathrm{W}_{1}\end{array}$ & $\begin{array}{c}A_{Y E . .}=A_{\text {Electr... }} \\
\mathrm{X} \mathrm{W}_{2}\end{array}$ \\
\hline Sector ... & $\mathrm{A}_{\ldots a}$ & $\mathrm{~A}_{\ldots \mathrm{b}}$ & $\mathrm{A}_{\ldots . \mathrm{c}}$ & $\begin{array}{c}\mathrm{A}_{. . \mathrm{FE}}= \\
\text { A..Electr. X W } 1\end{array}$ & $\begin{array}{c}\text { A.. YE }= \\
\text { A..Electr. X W2 }\end{array}$ & A... \\
\hline
\end{tabular}

The basic assumption in this disaggregation step is newly disaggregated electricity sectors supply electricity proportionally to their market share to the other sectors of the economy. This is a fairly reasonable assumption since electricity is a homogenous source of energy regardless of its source. Therefore, this homogeneity of electricity yields a chance of a healthy comparative analysis. This is one of the reasons why the electricity sector is taken in the center of analysis, instead of the general energy sector. Since different industries may demand and supply different types of energy that prevents the implication of the disaggregation technic explained.

The newly created $72 \times 72$ input-output table isn't, however, ready to use. While due to this homogeneity newly created sectors assumed to supply electricity proportionally to their market share, their input demand from other sectors may differ one from the other, because of different production technics and technologies. Therefore, at this stage cost structure dataset for the manufacturing and installation phase supplied by GarretPeltier (2017) used to rearrange the input demands of the electricity sectors. For the operation and maintenance phase, on the other hand, data supplied by Tourkolias and Mirasgedis(2011) together with the American National Renewable Energy Laboratory database (Nrel, 2018) used. According to the information gained from 
those databases, the cost structure of all electricity sectors is rearranged and two different input-output tables are created for both of the phases.

At the final stage, using the latest versions of the $72 \times 72$ input-output tables generated, Leontief Inverse Matrices $(\mathrm{I}-\mathrm{A})^{-1}$ are created. Subsequently, the methodology applied at the Final Demand Approach repeated, and ERM: (E/O).(I-A) $)^{-1}$ is created for both of the phases. To simulate the employment effects of one million dollars of spending $(\Delta \mathrm{Y})$ in each of the electricity sectors, for the two different phases, the following equation is applied;

$$
\Delta \mathrm{E}=\mathrm{ERM} . \Delta \mathrm{Y}
$$

After the effects of one million dollars spending estimated for both phases, the $72 \times 72$ input-output tables rearranged again to the size of $73 \times 73$ to endogenize the household sector as it was done in the Final Demand Approach. Repeating all of the previous procedures to the newly created matrix, the induced employment effect is captured besides the direct and indirect employment effects for both phases. After all of those procedures are done, plenty of results have been acquired that will be covered in the next section.

\section{RESULTS AND DISCUSSION}

Due to the use of different models, phases, sectors, and effects, multi-layered estimations have been achieved. However, the remarkable point among all of these results is, in all alternative estimates, electricity sectors based on renewable resources are always more effective than fossil-based electricity sectors in terms of employment creation. (Figure 1, Figure 2)

Fig. 1. Final Demand Approach Job Creation Estimates for \$ 1 M Investment

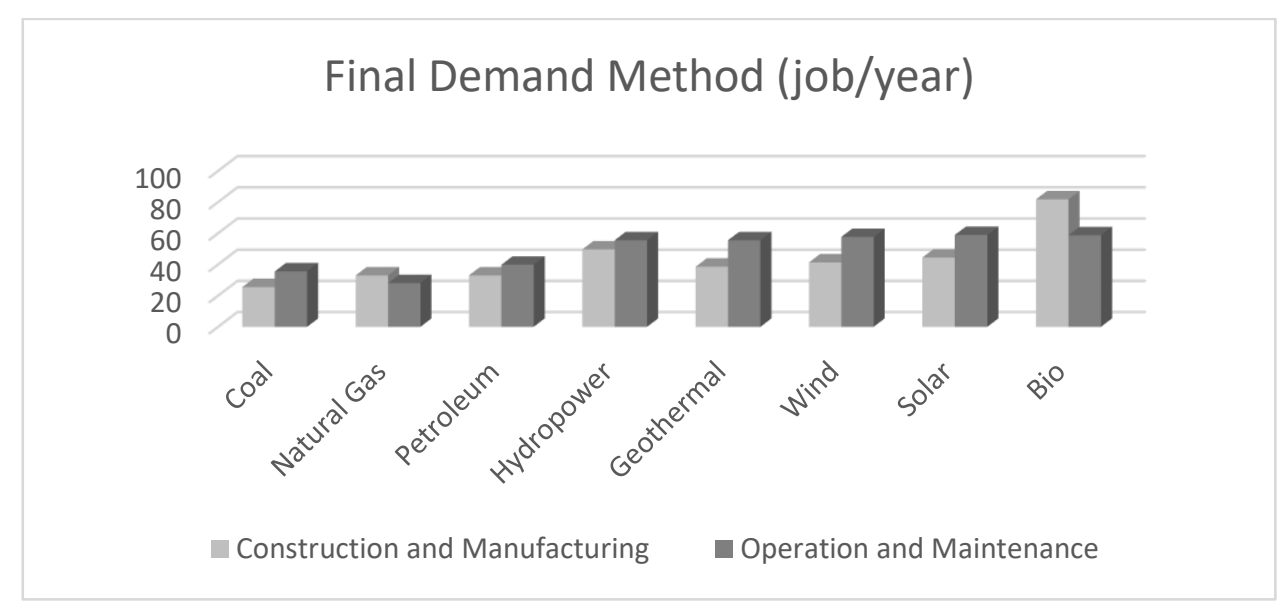

Fig. 2. Complete Inclusion Approach Job Creation Estimates for \$ 1 M Investment

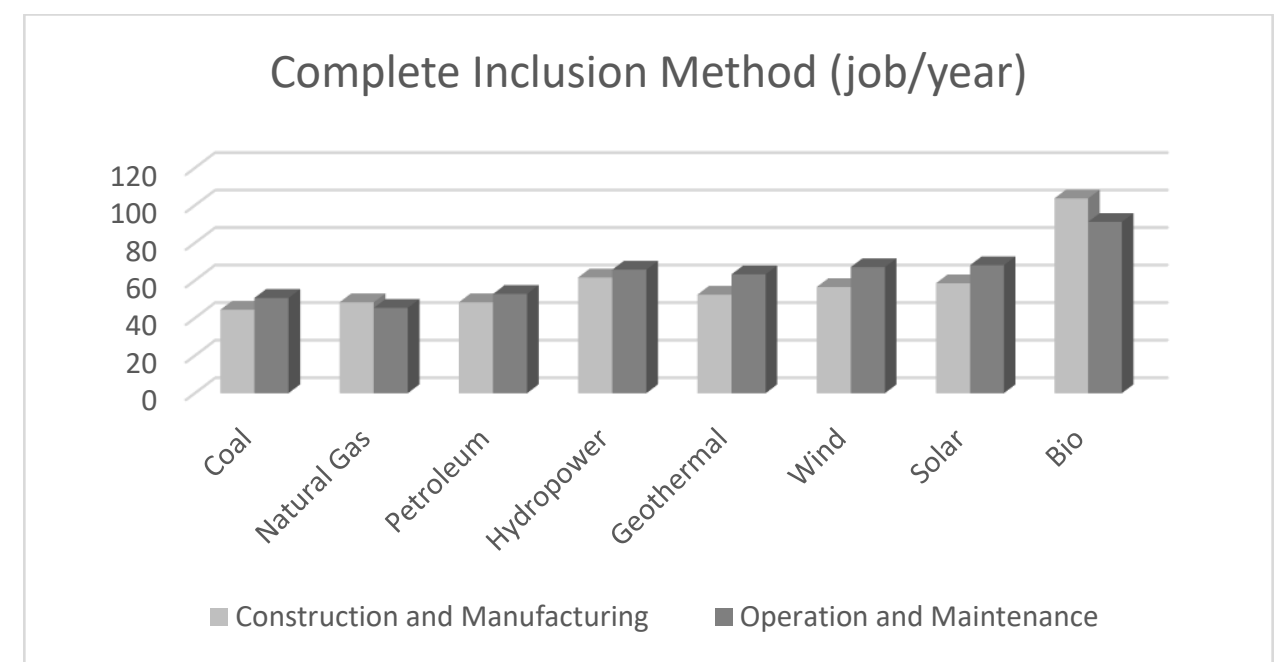

According to both approaches in the manufacturing and installation phase, bioenergy based electricity sector is the most effective sector followed by the hydroelectricity sector. In the fossil energy-based electricity sector there are two different subsectors, coal, and natural gas/petroleum, in contrast to the operation and 
maintenance phase where three fossil-based sectors are investigated. Since the cost structure of operation and maintenance phase natural gas and petroleum sectors are handled separately. For both approaches, the natural gas and petroleum sector have more capacity in terms of employment generation than the coal-based electricity sector.

Another marked point in the estimation results of the manufacturing and installation phase is the weight of the induced job effect in total. According to final demand approach estimation results, for all of the sectors, more than the $\% 30$ of newly created jobs comes from the induced employment effect. For the complete inclusion approach estimation results, however, this ratio is even higher than $\% 50$ for most of the sectors (Table 3)

Table 3 Manufacturing and installation Phase Employment Effect

\begin{tabular}{lccccccc}
\hline \multicolumn{7}{c}{ Final Demand Method } \\
\hline Type of Effect & Coal & $\begin{array}{c}\text { Nat.Gas/P } \\
\text { etroleum }\end{array}$ & Hydraulic & $\begin{array}{c}\text { Geotherm } \\
\text { al }\end{array}$ & Wind & Solar & Bio \\
\hline Direct + Indirect & 13,97 & 13,91 & 25,77 & 24,21 & 26,57 & 26,07 & 50,25 \\
Induced & 11,57 & 19,06 & 23,90 & 14,35 & 14,76 & 18,31 & 31,50 \\
Total & 25,54 & 32,97 & 49,67 & 38,56 & 41,33 & 44,38 & 81,75 \\
\hline \multicolumn{7}{c}{ Complete Inclusion Method } \\
\hline Direct & 10,06 & 9,45 & 12,90 & 10,37 & 12,95 & 13,04 & 36,64 \\
Indirect & 7,85 & 7,83 & 13,12 & 11,13 & 13,17 & 13,05 & 26,35 \\
Induced & 26,48 & 31,1 & 35,55 & 30,92 & 30,37 & 32,39 & 40,78 \\
Total & 44,39 & 48,38 & 61,57 & 52,42 & 56,49 & 58,48 & 103,77 \\
\hline Note: Employment effects are per one million dollars spending and annual jobs. & & &
\end{tabular}

For the operation and maintenance phase, bioenergy and solar energy-based electricity sectors are the most effective considering the estimation results of the final demand approach. For the complete inclusion method, however, bioenergy is by far the most effective sector which is followed by the solar energy sector. Similar to the manufacturing and installation phase, the induced effect is once again the most important element in the employment generation for both final demand and complete inclusion approaches (Table 4). This is particularly important since in the literature a substantial volume of studies does not consider the induced effect which may result in biased estimations.

Table 4 Operation and Maintenance Phase Employment Effect

\begin{tabular}{|c|c|c|c|c|c|c|c|c|}
\hline \multicolumn{9}{|c|}{ Final Demand Approach } \\
\hline Type of Effect & Coal & $\begin{array}{c}\text { Petroleu } \\
m\end{array}$ & $\begin{array}{c}\text { Natural } \\
\text { Gas }\end{array}$ & $\begin{array}{c}\text { Hydrauli } \\
c\end{array}$ & $\begin{array}{c}\text { Geother } \\
\text { mal }\end{array}$ & Wind & Solar & Bio \\
\hline Direct + Indirect & 13,23 & 12,22 & 12,54 & 15,76 & 15,76 & 16,35 & 13,76 & 19,43 \\
\hline Induced & 22,32 & 15,84 & 27,30 & 39,77 & 39,77 & 41,31 & 45,13 & 39,30 \\
\hline Total & 35,55 & 28,06 & 39,84 & 55,53 & 55,53 & 57,66 & 58,89 & 58,73 \\
\hline \multicolumn{9}{|c|}{ Complete Inclusion Approach } \\
\hline Direct & 10,08 & 9,46 & 9,50 & 12,90 & 10,38 & 12,96 & 13,05 & 36,65 \\
\hline Indirect & 7,44 & 6,88 & 7,03 & 8,80 & 8,82 & 9,15 & 7,71 & 10,86 \\
\hline Induced & 33,18 & 29,08 & 36,27 & 44,03 & 44,02 & 44,98 & 47,32 & 43,73 \\
\hline Total & 50,70 & 45,42 & 52,80 & 65,73 & 63,22 & 67,09 & 68,08 & 91,24 \\
\hline
\end{tabular}

Another point that draws attention in the estimation results is that bioenergy based electricity sector is among one of the two most effective sectors in all of the results. This may be due to its agricultural components of the sector which is highly labor-intensive. The fact that the agricultural sector in Turkey is the most laborintensive sector (Table 5) makes the bioenergy based electricity sector come to the fore in terms of employment generation.

Table 5 Labor Intensity By Sectors

\begin{tabular}{cccc}
\hline Sectors & $\begin{array}{c}\text { Total Revenue } \\
\text { (Thousand TL) }\end{array}$ & $\begin{array}{c}\text { Total } \\
\text { Employment }\end{array}$ & Labor Intensity \\
\hline Agriculture, Forestry and fishing & 178744670 & 6097000 & 0,0341 \\
Mining and quarrying & 32738610 & 113000 & 0,0034 \\
Manufacturing & 566448244 & 4420000 & 0,0078 \\
\hline
\end{tabular}




\begin{tabular}{cccc} 
Electricity, gas, steam, water sup. etc. & 154720780 & 218000 & 0,0014 \\
Construction & 297839261 & 1709000 & 0,0057 \\
Wholesale and retail trade & 288644429 & 3502000 & 0,0121 \\
Transportation and storage & 272993907 & 1095000 & 0,0040 \\
Accom. and food service activities & 85421969 & 1206000 & 0,0141 \\
Information and communication & 68623700 & 238000 & 0,0034 \\
Financial, insurance activities & 73445666 & 264000 & 0,0035 \\
Real estate activities & 172460279 & 184000 & 0,0010 \\
Prof., scientific, technical activities & 70768082 & 507000 & 0,0071 \\
Admin. And support service act. & 66318490 & 924000 & 0,0139 \\
Public administration and defense & 91378512 & 1458000 & 0,0159 \\
Education & 72260125 & 1224000 & 0,0169 \\
Human health and social work act. & 71655470 & 808000 & 0,0112 \\
Arts, entertainment and recreation & 22436609 & 108000 & 0,0048 \\
Other social, comm., personal service act. & 32369686 & 748000 & 0,0231 \\
\hline Sot
\end{tabular}

Source: (Turkstat, 2016; Turkstat, 2012a.)

The distribution of newly created jobs is also important, which is mostly neglected in the literature since this distribution must match with the ability of the labor force in Turkey. Because it is impossible to discuss the immense volume of results associated with the distribution of newly created jobs for all of the sectors, all of the phases and for two different methodologies, the most effective sectors of fossil-based and renewablebased electricity sectors analyzed in table 6 for each section.

Original estimations of distribution of newly created jobs were in the form of $65 \times 65$ and $73 \times 73$ sectors. To simplify the results, however, they are aggregated to $19 \mathrm{x} 19$ form which is designed according to Turkstat's "Economic Activity by Years and Sex, Nace Rev.2" classification (Turkstat, 2016) and with the addition of the household, sector created in the analysis to capture the induced employment effects. Most of the newly created jobs arise in Electricity, gas, steam, water supply, sewerage, etc. sector due to the direct employment effect. Other sectors such as; Agriculture, Forestry and fishing sector, Manufacturing sector, Wholesale and retail trade sector, Transportation and storage sector are also important in the employment generation. In the fossil-based electricity sectors, however, Mining and quarrying sectors take an important place (Table 6).

Table 6 Distribution of newly created jobs for some sectors

\begin{tabular}{|c|c|c|c|c|c|c|c|c|}
\hline \multirow{5}{*}{ Sectors } & \multirow{2}{*}{\multicolumn{4}{|c|}{ Fossil Energy }} & & & & \\
\hline & & & & & \multicolumn{4}{|c|}{ Renewable Energy } \\
\hline & \multicolumn{2}{|c|}{ Final Demand } & \multicolumn{2}{|c|}{$\begin{array}{l}\text { Complete } \\
\text { Inclusion }\end{array}$} & \multicolumn{2}{|c|}{ Final Demand } & \multicolumn{2}{|c|}{$\begin{array}{l}\text { Complete } \\
\text { Inclusion }\end{array}$} \\
\hline & $\begin{array}{l}\text { C.M. } \\
\text { Nat. }\end{array}$ & $\begin{array}{c}\text { O.M } \\
\text { Nat. Gas }\end{array}$ & $\begin{array}{l}\text { C.M. } \\
\text { Nat. }\end{array}$ & $\begin{array}{c}\text { O.M } \\
\text { Nat. Gas }\end{array}$ & $\begin{array}{l}\text { C.M. } \\
\text { Bio }\end{array}$ & $\begin{array}{l}\text { O.M. } \\
\text { Solar }\end{array}$ & $\begin{array}{l}\text { C.M. } \\
\text { Bio }\end{array}$ & $\begin{array}{l}\text { O.M } \\
\text { Bio }\end{array}$ \\
\hline & \multicolumn{4}{|c|}{ Gas/Pet. $\quad$ Gas/Pet. } & & & & \\
\hline Agriculture, Forestry and fishing (A) & 1,39 & 2,07 & 2,30 & 2,75 & 37,01 & 2,99 & 22,33 & 3,18 \\
\hline Mining and quarrying (B) & 2,92 & 4,07 & 1,65 & 2,32 & 0,10 & 0,05 & 0,09 & 0,07 \\
\hline Manufacturing $\quad$ (C) & 7,38 & 2,59 & 5,13 & 2,44 & 5,77 & 8,12 & 4,30 & 4,75 \\
\hline $\begin{array}{l}\text { Electricity, gas, steam, water supply, } \\
\text { sewerage etc. (D+E) }\end{array}$ & 0,12 & 0,18 & 9,61 & 9,68 & 0,14 & 0,19 & 37,84 & 36,86 \\
\hline Construction $(\mathrm{F})$ & 0,05 & 0,10 & 0,05 & 0,09 & 3,18 & 0,14 & 1,81 & 0,10 \\
\hline Wholesale and retail trade $(\mathrm{G})$ & 1,61 & 1,73 & 1,65 & 1,76 & 2,24 & 2,31 & 2,08 & 5,97 \\
\hline Transportation and storage $(\mathrm{H})$ & 2,29 & 0,77 & 1,51 & 0,66 & 0,68 & 0,71 & 0,63 & 2,75 \\
\hline $\begin{array}{l}\text { Accommodation and food service } \\
\text { activities (I) }\end{array}$ & 0,35 & 0,54 & 0,57 & 0,70 & 0,63 & 0,84 & 0,08 & 0,84 \\
\hline Information and communication $(\mathrm{J})$ & 0,08 & 0,20 & 0,10 & 0,16 & 0,14 & 0,30 & 0,12 & 0,18 \\
\hline Financial, insurance activities $\quad(\mathrm{K})$ & 0,15 & 2,23 & 0,14 & 1,31 & 0,17 & 3,78 & 0,16 & 0,23 \\
\hline Real estate activities $\quad$ (L) & 0,06 & 0,11 & 0,09 & 0,12 & 0,1 & 0,55 & 0,10 & 0,25 \\
\hline $\begin{array}{l}\text { Professional, scientific and } \\
\text { technical activities }(\mathrm{M})\end{array}$ & 0,25 & 1,71 & 0,23 & 1,04 & 2,26 & 0,69 & 1,35 & 0,36 \\
\hline Admin. And support service act. (N) & 0,50 & 0,85 & 0,46 & 0,66 & 0,67 & 0,86 & 0,57 & 0,66 \\
\hline Public administration and defense $(\mathrm{O})$ & 0,03 & 0,05 & 0,05 & 0,05 & 0,68 & 0,07 & 0,07 & 0,07 \\
\hline Education $(\mathrm{P})$ & 0,09 & 0,16 & 0,14 & 0,19 & 0,16 & 0,25 & 0,19 & 0,21 \\
\hline Human health and social work act. (Q) & 0,04 & 0,06 & 0,07 & 0,09 & 0,07 & 0,10 & 0,09 & 0,10 \\
\hline Arts, entertainment and recreation $(\mathrm{R})$ & 0,02 & 0,03 & 0,03 & 0,05 & 0,0432 & 0,05 & 0,05 & 0,05 \\
\hline
\end{tabular}




\begin{tabular}{lccccccccc}
$\begin{array}{l}\text { Other social, community } \\
\text { personal service activities }\end{array}$ & $\begin{array}{c}\text { and } \\
\text { Household }\end{array}$ & 0,20 & 0,3 & 0,30 & 0,37 & 0,35 & 0,44 & 0,41 & 0,46 \\
Total & & 15,34 & 22,006 & 24,19 & 28,24 & 27,89 & 36,35 & 31,73 & 34,05 \\
Total & & 32,97 & 39,85 & 48,38 & 52,8 & 81,75 & 58,89 & 103,76 & 91,24 \\
\hline
\end{tabular}

For the reason that studies in the literature mostly concentrated on developed countries and there is a limited amount of studies conducted for developing countries like Turkey, it will be useful to compare the results in the literature with the results that have been found. However, due to the excessive volume of results and heterogeneity among them, makes some limitation mandatory for sound comparison. Since some studies are associated with employment generation to the production capacity of powerplants in terms of GWh or production in terms of GWh, renders them readily incomparable to our study. Therefore, because our study measures employment generation resulting from new financial investments, similar studies opted for the comparison as seen in table 7.

Table 7 Comparisons of Results with Other Studies Results'

\begin{tabular}{|c|c|c|c|c|c|c|c|}
\hline Study & Meth. & Region & Sector & $\begin{array}{c}\text { M.C. } \\
\text { Dir. }+ \text { Ind. }\end{array}$ & $\begin{array}{c}\text { M.C. } \\
\text { Dir. }+ \text { Ind }+ \\
\text { Induced }\end{array}$ & $\begin{array}{c}\text { O.M. } \\
\text { Dir. }+ \text { Ind. }\end{array}$ & $\begin{array}{c}\text { O.M. } \\
\text { Dir. }+ \text { Ind }+ \\
\text { Induced }\end{array}$ \\
\hline Our Study & F.D. & Turkey & Hydropower & 25,78 & 49,68 & 15,76 & 55,53 \\
\hline Our Study & F.D. & Turkey & Geothermal & 24,21 & 38,57 & 15,76 & 55,53 \\
\hline Our Study & F.D. & Turkey & Wind & 26,57 & 41,33 & 16,35 & 57,67 \\
\hline Our Study & F.D. & Turkey & Solar & 26,07 & 44,39 & 13,76 & 58,89 \\
\hline Our Study & F.D. & Turkey & Bioenergy & 50,25 & 81,75 & 19,43 & 58,74 \\
\hline Our Study & C.I. & Turkey & Hydropower & 26,03 & 61,57 & 21,70 & 65,73 \\
\hline Our Study & C.I. & Turkey & Geothermal & 21,51 & 52,42 & 19,20 & 63,22 \\
\hline Our Study & C.I. & Turkey & Wind & 26,13 & 56,49 & 22,10 & 67,09 \\
\hline Our Study & C.I. & Turkey & Solar & 26,10 & 58,48 & 20,75 & 68,08 \\
\hline Our Study & C.I. & Turkey & Bioenergy & 63,01 & 103,77 & 47,51 & 91,24 \\
\hline Çetin, Eğrican (2011) & Fac.Mult. & Turkey & Solar & 15,24 & 30,49 & 15,24 & 30,49 \\
\hline Erdoğdu, Karaca(2016) & Com.Soft. & Turkey & Solar & 11,45 & 19,74 & 20,72 & 28,72 \\
\hline Markaki (2013) & I.O. & Greece & Wind 1 & 14,13 & 17,67 & 14,13 & 17,67 \\
\hline Markaki (2013) & I.O. & Greece & Wind 2 & 15,25 & 19 & 15,25 & 19 \\
\hline Markaki (2013) & I.O. & Greece & Solar & 14,73 & 18,46 & 14,73 & 18,46 \\
\hline Markaki (2013) & I.O. & Greece & Hydropower & 16,55 & 20,25 & 16,55 & 20,25 \\
\hline Markaki (2013) & I.O. & Greece & Geothermal & 14,08 & 17,86 & 14,08 & 17,86 \\
\hline Markaki (2013) & I.O. & Greece & Bioenergy & 17,25 & 20,81 & 17,25 & 20,81 \\
\hline Garret-Peltier(2017) & F.D. & U.S.A. & Wind & 7,52 & - & - & - \\
\hline Garret-Peltier(2017) & F.D. & U.S.A. & Solar & 7,24 & - & - & - \\
\hline Garret-Peltier(2017) & F.D. & U.S.A. & Bioenergy & 7,65 & - & - & - \\
\hline Garret-Peltier(2017) & F.D. & U.S.A. & Geothermal & 7,40 & - & - & - \\
\hline Garret-Peltier(2017) & F.D. & U.S.A. & Hydropower & 7,53 & - & - & - \\
\hline Pollin(2009) & I.O. & Ontario & Hydropower & 14.2 & - & - & - \\
\hline Pollin(2009) & I.O. & Ontario & Wind 1 & 14.7 & - & - & - \\
\hline Pollin(2009) & I.O. & Ontario & Wind 2 & 15,8 & - & - & - \\
\hline Pollin(2009) & I.O. & Ontario & Bioenergy & 16.4 & - & - & - \\
\hline Chen(2019) & I.O. & China & Solar & 100,1 & - & - & - \\
\hline Chen(2019) & I.O. & China & Wind & 100,1 & - & - & - \\
\hline Chen(2019) & I.O. & China & Bioenergy & 286,4 & - & - & - \\
\hline
\end{tabular}

In general, it is seen that although the estimates reached in our study are higher, they are within the ranges of the literature findings. The reasons for the high employment estimates can be explained with a few factors. First, the fact that employment effects are higher in Turkey compared to other studies may indicate the differences in the labor intensity of the sectors among countries.

Fig. 3. Hourly labor costs for some countries in 2017 PPPs US dollars, latest year. 


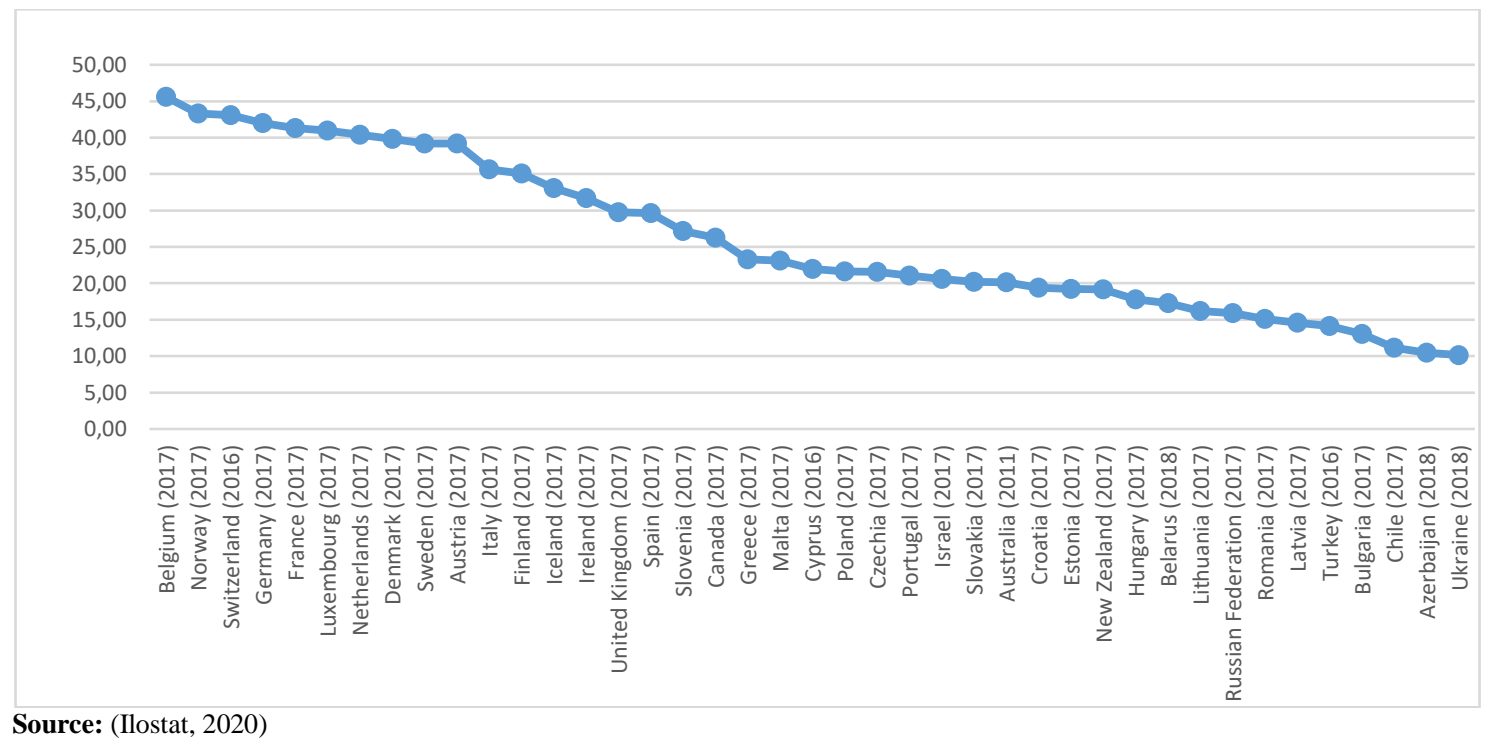

Another important factor that may explain the higher employment estimates in our study compared to other studies is the lower labor costs in Turkey compared to developed countries (Figure 3). Lower wages may be an important factor explaining higher employment generation, since investors may prefer labor-intensive production technologies rather than high-cost capital-intensive production technologies. Especially considering Turkey's dependency on foreign countries in financial means or a significant reliance on imported inputs and weak capital goods sector, renders this option highly reasonable (Becker, 2016).

Additionally, a third factor may be particular production technologies, and the supply chain structure of the energy sectors in Turkey may cause a higher multiplier effect and employment effect. This factor, however, may be expected to be less probable compared to other factors that have mentioned, since rapid technological dissemination seen throughout the recent decades in the renewable energy sectors (Koengkan, et. al., 2019). Therefore differences in the production technologies among countries seem to be less plausible.

Nonetheless, high employment generation estimates are not sufficient to be able to fully utilize the employment benefits. The potential capacity of renewable resources in a region is also crucial. Since renewable resources are not the kind of sources to be imported. Therefore, to be able to fully exploit the employment benefits estimated, renewable resources must be sufficient and easily accessible.

In this case, Turkey is very rich in almost all types of renewable energy sources. Turkey with the 1000 $1450 \mathrm{kWh} / \mathrm{m}^{2}$ year value, excluding Spain, has more solar energy potential than all of the European Union countries (Cengiz and Mamiş, 2015). For wind energy, with the $166 \mathrm{TWh} /$ year technical potential, Turkey is among the richest countries in Europe (Dursun and Gokcol, 2014). Considering Turkey is the seventh-largest agricultural producer in the world, the bioenergy may be a very important sector too (Rincon et. al., 2019). Moreover, in terms of hydropower potential, with $440 \mathrm{TWh}$ /year, Turkey has the second richest resources in Europe after Norway (Yuksel, 2012). Therefore the employment generation potential of the renewable energybased electricity sector in Turkey compared to the fossil energy-based electricity sector is not only on theoretical estimations. On the contrary, with these rich resource potential, renewable energy may be a strong engine for sustainable development in Turkey.

\section{CONCLUSION}

Environmental, economic, and social elements of sustainable development are tightly interconnected and high unemployment in Turkey negatively affects all of them. In this perspective, the renewable energy sector in Turkey, with her rich resources, may be an important prescription for the unemployment problem and other concerns of sustainable development.

From the microeconomic perspective, the renewable energy sector may be an important tool for the employment generation. Moreover, being a domestic resource may ease the current account deficit and other associated economic problems too. However, at the macroeconomic level, while new jobs are created in the renewable energy sector, other jobs may disappear in the conventional fossil energy sector. Therefore, two different methodologies were implemented to see the net employment effect of the transition from the fossilbased energy structure to a renewable-based energy structure.

According to both of the methodologies and for both of the phases, manufacturing/installation and operation/maintenance, all types of renewable-based electricity sectors are more effective than fossil-based 
electricity sectors in terms of employment generation. The interesting point among those finding is, the induced effect constitutes $35 \%$ to $75 \%$ of the total employment generation effect depending on the estimation method and phase. Taking into account that induced effect frequently disregarded in the literature, this is a particularly important finding.

Considering the unemployment rate in Turkey rose to a peak of $14,7 \%$ and the youth unemployment rate rose to a peak of $26,1 \%$ in 2019 (Turkstat, 2019a), those findings are particularly important. According to those estimations, the renewable energy sector may be an alternative way to growth and employment creation in Turkey without worrying about environmental degradation.

Moreover, according to estimation results, bioenergy is one of the two most effective sectors in terms of employment generation. This may be particularly helpful for the structural unemployment problem in Turkey, that arises due to skill mismatch between industry requirements and the newly immigrated labor force which is only equipped with agricultural skills. Furthermore, by providing jobs to residents of rural regions in Turkey, through the bioenergy sector, internal migration and associated socioeconomics problems may be mitigated too.

Also, the renewable energy sector may have other benefits too, such as political and geostrategic benefits in the context of energy independence. However, to utilize all of those benefits, policymakers must agree on the strategic importance of the sector and more support and subsidies should be granted to the sector. Since, despite the recent developments, the renewable energy sector has higher costs compared to fossil energy sectors. Besides, to absorb all of the estimated employment benefits and prevent job leakages to other competing countries domestic production must be supported in the manufacturing part of the sector. 


\section{REFERENCES}

<http://www.tuik.gov.tr/ZipGetir.do?id=15852> [Accessed March 05, 2019].

AA, 2019. <https://www.aa.com.tr/tr/ekonomi/enerji-ithalati-faturasi-2019da-yuzde-4-2-azaldi/1726127> [Accessed May 02, 2020].

Akçoraoğlu, A. (2010). Employment, economic growth and labor market performance: The case of Turkey. Ekonomik Yaklasim, 21:77, 101-114.

and Sustainable Energy Reviews, 15:6, 2876-2886. doi: doi.org/10.1016/j.rser.2011.02.027

Ata, A. Y. (2011). Ücretler, işsizlik ve suç arasındaki ilişki: Yatay-kesit analizi. Çalışma ve Toplum, 4:31, 113-134

Becker, Joachim. (2016). Financialisation, Industry and Dependency in Turkey. Journal für Entwicklungspolitik. 32, 84 113. doi: 10.20446/JEP-2414-3197-32-1-84

Behrens, P., Rodrigues, J. F., Brás, T., \& Silva, C. (2016). Environmental, economic, and social impacts of feed-in tariffs: A Portuguese perspective 2000-2010. Applied energy, 173, 309-319. doi: https://doi.org/10.1016/j.apenergy.2016.04.044

Bell, Stephanie; Wray, L. Randall (2004). The war on poverty after 40 Years: a Minskyan assessment, Working Paper, No. 404, Levy Economics Institute of Bard College, Annandale-on-Hudson, NY

Blazejczak, J., Braun, F. G., Edler, D., \& Schill, W. P. (2014). Economic effects of renewable energy expansion: A modelbased analysis for Germany. Renewable and Sustainable Energy Reviews, 40, 1070-1080. doi: https://doi.org/10.1016/j.rser.2014.07.134

Bohlmann, H. R., Horridge, J. M., Inglesi-Lotz, R., Roos, E. L., \& Stander, L. (2019). Regional employment and economic growth effects of South Africa's transition to low-carbon energy supply mix. Energy policy, 128, 830837. doi: doi.org/10.1016/j.enpol.2019.01.065

Böhringer, C., Keller, A., \& Van der Werf, E. (2013). Are green hopes too rosy? Employment and welfare impacts of renewable energy promotion. Energy Economics, 36, 277-285. doi: https://doi.org/10.1016/j.eneco.2012.08.029

Bulavskaya, T., \& Reynès, F. (2018). Job creation and economic impact of renewable energy in the Netherlands. Renewable Energy, 119, 528-538. doi: https://doi.org/10.1016/j.renene.2017.09.039

Byun, K. J. (2010). The US housing bubble and bust: impacts on employment. Monthly Labor Review, 133:12.

Cai, W., Mu, Y., Wang, C., \& Chen, J. (2014). Distributional employment impacts of renewable and new energy-a case study of China. Renewable and Sustainable Energy Reviews, 39, 1155-1163. doi: https://doi.org/10.1016/j.rser.2014.07.136

Cai, W., Wang, C., Chen, J., \& Wang, S. (2011). Green economy and green jobs: Myth or reality? The case of China's power generation sector. Energy, 36:10, 5994-6003. doi: https://doi.org/10.1016/j.energy.2011.08.016

Caldes, N., Varela, M., Santamaría, M., \& Sáez, R. (2009). Economic impact of solar thermal electricity deployment in Spain. Energy Policy, 37(5), 1628-1636. doi: https://doi.org/10.1016/j.enpol.2008.12.022

Cameron, L., \& Van Der Zwaan, B. (2015). Employment factors for wind and solar energy technologies: A literature review. Renewable and Sustainable Energy Reviews, 45, 160-172. doi: https://doi.org/10.1016/j.rser.2015.01.001

Cansino, J. M., Cardenete, M. A., González-Limón, J. M., \& Román, R. (2014). The economic influence of photovoltaic technology on electricity generation: A CGE (computable general equilibrium) approach for the Andalusian case. Energy, 73, 70-79. doi: https://doi.org/10.1016/j.energy.2014.05.076

Cantore, N., Nussbaumer, P., Wei, M., \& Kammen, D. M. (2017). Promoting renewable energy and energy efficiency in Africa: a framework to evaluate employment generation and cost effectiveness. Environmental Research Letters, 12, 1-11, doi: https://doi.org/10.1088/1748-9326/aa51da

Cengiz, M. S., \& Mamis, M. S. (2015). Thermal Solar Energy Use and Turkey Analysis. Bitlis Eren University Journal of Science and Technology, 5:2.

Çetin, M., \& Eğrican, N. (2011). Employment impacts of solar energy in Turkey. Energy Policy, 39(11), 7184-7190. doi: https://doi.org/10.1016/j.enpol.2011.08.039

Chateau, J., \& Saint-Martin, A. (2013). Economic and employment impacts of climate change mitigation policies in OECD: A general-equilibrium perspective. International Economics, 135, 79-103. doi: https://doi.org/10.1016/j.inteco.2013.08.001

Cömertler, N., \& Kar, M. (2007). Türkiye'de suç oranının sosyo-ekonomik belirleyicileri: yatay kesit analizi. Ankara Üniversitesi SBF Dergisi , 62:02, 37-57, doi: doi.org/10.1501/SBFder_0000002018

Dasgupta, P., \& Ray, D. (1986). Inequality as a Determinant of Malnutrition and Unemployment: Theory. The Economic Journal, 96:384, 1011-1034. doi:10.2307/2233171

Dursun, B., \& Gokcol, C. (2014). Impacts of the Renewable Energy Law on the Developments of Wind Energy in Turkey. Renewable and Sustainable Energy Reviews, 40, 318-325. doi: https://doi.org/10.1016/j.rser.2014.07.185

Dursun, S., Aytaç, S., \& Topbaş, F. (2011). The effects of unemployment and income on crime: a panel data analysis on Turkey. Annales, XLIII, 125-138

Dvorak, P., Martinat, S., Van der Horst, D., Frantal, B., \& Tureckova, K. (2017). Renewable energy investment and job creation; a cross-sectoral assessment for the Czech Republic with reference to EU benchmarks. Renewable and Sustainable Energy Reviews, 69, 360-368. doi: https://doi.org/10.1016/j.rser.2016.11.158

Eigm, 2012. Energy Balance Tables 2012, <https://www.eigm.gov.tr/tr-TR/Denge-Tablolari/Denge-Tablolari> [Accessed June 16, 2018]. 
Ercan, H. (2007). Youth employment in Turkey. Ankara: International Labour Office.

Erdal, L. (2012). Türkiye'de Yenilenebilir Enerji Yatırımları ve İstihdam Yaratma Potansiyeli. Sosyal ve Beşeri Bilimler Dergisi, 4:1, 171-181.

Erdoğdu, M. M., \& Karaca, C. (2016). An Industrial Policy Recommendation for Raising Solar Energy Investments in Turkey and Its Possible Employment Effect. In M. M. Erdoğdu, A. Y. Mermod, \& O. B. Yıldırım (Eds.), Social and Economic Perspectives on Sustainability, London and Istanbul: IJOPEC Publication. ISBN: 978-0-9932118$1-2$.

Erkan Özata (2014). Sustainability of current account deficit with high oil prices: Evidence from Turkey. International Journal of Economic Sciences, 3:2, 71-88.

Fanning, T., Jones, C., \& Munday, M. (2014). The regional employment returns from wave and tidal energy: A Welsh analysis. Energy, 76, 958-966. doi: https://doi.org/10.1016/j.energy.2014.09.012

Garrett-Peltier, H. (2017). Green Versus Brown: Comparing the Employment İmpacts of Energy Efficiency, Renewable Energy, and Fossil Fuels Using An Input-Output Model. Economic Modelling, 61, 439-447. doi: https://doi.org/10.1016/j.econmod.2016.11.012

Guenther-Lübbers, W., Bergmann, H., \& Theuvsen, L. (2016). Potential analysis of the biogas production-as measured by effects of added value and employment. Journal of Cleaner Production, 129, 556-564. doi: https://doi.org/10.1016/j.jclepro.2016.03.157

Hayati, A. K. S. U., \& Akkuş, Y. (2010). Türkiye'de Mala Karşı Suçların Sosyoekonomik Belirleyicileri Üzerine Bir Deneme: Sınır Testi Yaklaşımı (1970-2007). Sosyoekonomi, 11:11, 191-214 doi: https://dergipark.org.tr/tr/pub/sosyoekonomi/issue/21071/226869

Heindl, Peter \& Voigt, Sebastian (2012). Employment effects of regional climate policy: The case of renewable energy promotion by feed-in tariffs, ZEW Discussion Papers, No. 12-066, Zentrum für Europäische Wirtschaftsforschung (ZEW), Mannheim.

Henriques, C. O., Coelho, D. H., \& Cassidy, N. L. (2016). Employment impact assessment of renewable energy targets for electricity generation by 2020-An IO LCA approach. Sustainable Cities and Society, 26, 519-530. doi: https://doi.org/10.1016/j.scs.2016.05.013

Hillebrand, B., Buttermann, H. G., Behringer, J. M., \& Bleuel, M. (2006). The expansion of renewable energies and employment effects in Germany. Energy Policy, 34:18, 3484-3494. doi: https://doi.org/10.1016/j.enpol.2005.06.017

Ilostat, 2020. Labour costs across countries, <https://ilostat.ilo.org/topics/labour-costs/> [Accessed August 1, 2020].

Islam, R. (2004). The nexus of economic growth, employment and poverty reduction: An empirical analysis. International Labour Office. Issues in Employment and Poverty, Discussion Paper No.14

Jülide Yildirim \& Selami Sezgin (2003). Military expenditure and employment in

Kahouli, S., \& Martin, J. C. (2018). Can offshore wind energy be a lever for job creation in France? Some insights from a local case study. Environmental Modeling \& Assessment, 23, 203-227. doi: https://doi.org/10.1007/s10666-0179580-4

Kammen, Daniel M. Kapadia, Kamal and Fripp, Matthias (2004) Putting Renewables to Work: How Many Jobs Can the Clean Energy Industry Generate? RAEL Report, University of California, Berkeley.

Karaca, C., Ulutaş, A., \& Eşgünoğlu, M. (2017). Türkiye'de optimal yenilenebilir enerji kaynağının COPRAS yöntemiyle tespiti ve yenilenebilir enerji yatırımlarının istihdam artırıcı etkisi. Maliye Dergisi, 172, 111-132.

Kis, Z., Pandya, N., \& Koppelaar, R. H. (2018). Electricity generation technologies: Comparison of materials use, energy return on investment, jobs creation and CO2 emissions reduction. Energy Policy, 120, 144-157. doi: https://doi.org/10.1016/j.enpol.2018.05.033

Koengkan, M., Poveda, Y. E., \& Fuinhas, J. A. (2019). Globalisation as a motor of renewable energy development in Latin America countries. GeoJournal, 1-12. doi: https://doi.org/10.1007/s10708-019-10042-0

Lehr, U., Lutz, C., \& Edler, D. (2012). Green jobs? Economic impacts of renewable energy in Germany. Energy Policy, 47, 358-364. doi: doi.org/10.1016/j.enpol.2012.04.076

Lehr, U., Mönnig, A., Missaoui, R., Marrouki, S., \& Salem, G. B. (2016). Employment from renewable energy and energy efficiency in Tunisia-new insights, new results. Energy Procedia, 93, 223-228. doi: https://doi.org/10.1016/j.egypro.2016.07.174

Leontief, W. (1986). Input-Output Economics. (2. Ed.). New York: Oxford University

Llera, E., Scarpellini, S., Aranda, A., \& Zabalza, I. (2013). Forecasting job creation from renewable energy deployment through a value-chain approach. Renewable and Sustainable Energy Reviews, 21, 262-271. doi: https://doi.org/10.1016/j.rser.2012.12.053

Lund, H., \& Hvelplund, F. (2012). The economic crisis and sustainable development: The design of job creation strategies by use of concrete institutional economics. Energy, 43:1, 192-200. doi: https://doi.org/10.1016/j.energy.2012.02.075

Markaki, M., Belegri-Roboli, A., Michaelides, P., Mirasgedis, S., \& Lalas, D. P. (2013). The impact of clean energy investments on the Greek economy: An input-output analysis (2010-2020). Energy Policy, 57, 263-275. doi: https://doi.org/10.1016/j.enpol.2013.01.047 
Markandya, A., Arto, I., González-Eguino, M., \& Román, M. V. (2016). Towards a green energy economy? Tracking the employment effects of low-carbon technologies in the European Union. Applied energy,179,1342-1350. doi: doi.org/10.1016/j.apenergy.2016.02.122

Mathew Forstater (1999) Functional Finance and Full Employment: Lessons from Lerner for Today, Journal of Economic Issues, 33:2, 475-482, doi:10.1080/00213624.1999.11506180

Matumoto, Naoya \& Hondo, Hiroki. (2011). Analysis on Employment Effects of the Introduction of Renewable Energy Technologies Using an Extended Input-output Table. Journal of the Japan Institute of Energy. 90:3, 258-267. doi: https://doi.org/10.3775/jie.90.258

Miller, R. E., and Blair, P. D. (2009). Input-Output Analysis: Foundations and Extensions (2nd Ed.). New York: Cambridge University Press.

Mills, E. (2016). Job Creation and Energy Savings Through A Transition To Modern Off-Grid Lighting. Energy for Sustainable Development, 33, 155-166. doi: https://doi.org/10.1016/j.esd.2016.06.001

Moreno, B., \& Lopez, A. J. (2008). The effect of renewable energy on employment. The case of Asturias (Spain). Renewable and Sustainable Energy Reviews, 12(3), 732-751. doi: https://doi.org/10.1016/j.rser.2006.10.011

Mu, Y., Cai, W., Evans, S., Wang, C., \& Roland-Holst, D. (2018). Employment impacts of renewable energy policies in China: A decomposition analysis based on a CGE modeling framework. Applied Energy, 210, 256-267. doi: doi.org/10.1016/j.apenergy.2017.10.086

Neuwahl, F., Löschel, A., Mongelli, I., \& Delgado, L. (2008). Employment impacts of EU biofuels policy: combining bottom-up technology information and sectoral market simulations in an input-output framework. Ecological Economics, 68, 447-460. doi: https://doi.org/10.1016/j.ecolecon.2008.04.018

Nrel, 2018. JEDI Models. <https://www.nrel.gov/analysis/jedi/models.html>[Accessed June 18, 2018].

OECD, 2019. Labour force participation rate, <https://data.oecd.org/emp/labour-force-participation-rate.htm> [Accessed August 31, 2020].

Oliveira, C., Cassidy, N., \& Coelho, D. (2014, July). Employment effects of electricity generation from renewable energy technologies in the UK. In Proceedings of the 22nd International Input-Output Conference \& 4th Edition of the International School of IO Analysis, Lisbon, Portugal, 14-18.

Oliveira, C., Coelho, D., Da Silva, P. P., \& Antunes, C. H. (2013). How many jobs can the RES-E sectors generate in the Portuguese context?. Renewable and Sustainable Energy Reviews, 21, 444-455. doi: https://doi.org/10.1016/j.rser.2013.01.011

Ortega, M., del Río, P., Ruiz, P., \& Thiel, C. (2015). Employment effects of renewable electricity deployment. A novel methodology. Energy, 91, 940-951. doi: https://doi.org/10.1016/j.energy.2015.08.061

Press.

REN21, (2019). Renewables 2019 Global Status Report. Paris: REN21. Paris: REN21 Secretariat, ISBN 978-3-98189117-1

Rincon, L., Puri, M., Kojakovic, A., \& Maltsoglou, I. (2019). The contribution of sustainable bioenergy to renewable electricity generation in Turkey: Evidence based policy from an integrated energy and agriculture approach. Energy Policy, 130, 69-88. doi: https://doi.org/10.1016/j.enpol.2019.03.024

Robert Pollin \& Heidi Garrett-Peltier, (2009). "Building a Green Economy: Employment Effects of Green Energy Investments for Ontario," Political Economy Research Institute, University of Massachusetts at Amherst.

Rodríguez-Huerta, E., Rosas-Casals, M., \& Sorman, A. H. (2017). A societal metabolism approach to job creation and renewable energy transitions in Catalonia. Energy Policy, 108, 551-564. doi: https://doi.org/10.1016/j.enpol.2017.06.024

Rontos, K., Vavouras, J., \& Nagopoulos, N. (2016). Relations between national-regional unemployment and employment policies for a sustainable development in Greece. Social Cohesion and Development, 10:2, 81-97. doi:https://doi.org/10.12681/scad.9974

Schwartz, Jordan Z.; Andres, Luis A.; Dragoiu, Georgeta.(2009).Crisis in Latin America: Infrastructure Investment, Employment and the Expectations of Stimulus. World Bank Group. Policy Research working paper no: WPS 5009, Washington, D.C.

Simas, M., \& Pacca, S. (2014). Assessing employment in renewable energy technologies: A case study for wind power in Brazil. Renewable and Sustainable Energy Reviews, 31, 83-90. doi: https://doi.org/10.1016/j.rser.2013.11.046

Singh, V., \& Fehrs, J. E. (2001). The Work That Goes Into Renewable Energy. Renewable Energy Policy Project. Research Report No: 13

Sooriyaarachchi, T. M., Tsai, I. T., El Khatib, S., Farid, A. M., \& Mezher, T. (2015). Job creation potentials and skill requirements in, PV, CSP, wind, water-to-energy and energy efficiency value chains. Renewable and Sustainable Energy Reviews, 52, 653-668. doi: https://doi.org/10.1016/j.rser.2015.07.143

Stern, N. (2007). The Economics of Climate Change: The Stern Review. Cambridge: Cambridge University Press. doi:10.1017/CBO9780511817434

Tcherneva, P. R. (2008). The return of fiscal policy: Can the new developments in the new economic consensus be reconciled with the Post-Keynesian view?. Levy Economics Institute, Working Papers Series.

Tourkolias, C., Mirasgedis, S., Damigos, D., \& Diakoulaki, D. (2009). Employment benefits of electricity generation: A comparative assessment of lignite and natural gas power plants in Greece. Energy Policy, 37:10, 4155-4166. doi: doi.org/10.1016/j.enpol.2009.05.015 
Tourkolias, C., ve Mirasgedis, S. (2011). Quantification and Monetization of Employment Benefits Associated with Renewable Energy Technologies in Greece. Renewable

Turkey, Defence and Peace Economics, 14:2, 129-139, doi: 10.1080/10242690302919

Turkstat, 2012a. Employment by Economic Activity, Years and Gender, 2012 NACE Rev.2, <http://tuik.gov.tr/PreTablo.do?alt_id=1007> [Accessed January 03, 2018].

Turkstat, 2012b. Net electricity consumption according to sectors 2012, <http://www.tuik.gov.tr/PreTablo.do?alt_id=1029> [Accessed March 15, 2018].

Turkstat, 2012c. Industrial and residential electricity prices by consumption bands,

Turkstat, 2016. Input-Output Table, 2012. <http://tuik.gov.tr/PreTablo.do?alt_id=1021> [Accessed January 02, 2018].

Turkstat, 2019a. Labor Force Statistics, February 2019, <http://www.tuik.gov.tr/PreHaberBultenleri.do?id=30690> [Accessed August 31, 2020].

Turkstat, 2019b. $\quad$ Foreign Trade $\quad$ Statistics, $\quad$ December 2019 , <http://www.tuik.gov.tr/PreHaberBultenleri.do?id=33848> [Accessed August 31, 2020].

Turkstat, 2020a. Labor Force Statistics, May 2020, <http://www.tuik.gov.tr/PreHaberBultenleri.do?id=33789> [Accessed August 31, 2020].

Ünal, E. (2016). A comparative analysis of export growth in Turkey and China through macroeconomic and institutional factors. Evolutionary and Institutional Economics Review, 13, 57-91. https://doi.org/10.1007/s40844-016-00363

Wang, C., Zhang, W., Cai, W., \& Xie, X. (2013). Employment impacts of CDM projects in China's power sector. Energy policy, 59, 481-491. doi: doi.org/10.1016/j.enpol.2013.04.010.

Wei, M., Patadia, S., \& Kammen, D. M. (2010). Putting renewables and energy efficiency to work: How many jobs can the clean energy industry generate in the US?. Energy policy, 38:2, 919-931. doi: https://doi.org/10.1016/j.enpol.2009.10.044

William Vickrey (1997) A Trans-Keynesian Manifesto (Thoughts about an Asset-Based Macroeconomics), Journal of Post Keynesian Economics, 19:4, 495-510, doi:10.1080/01603477.1997.11490125

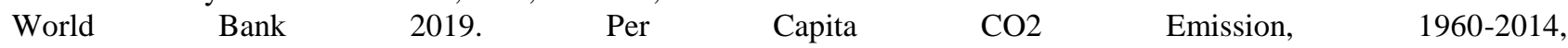
$<$ https://www.google.com.tr/publicdata/explore?ds=d5bncppjof8f9_\#!ctype=1\&strail=false\&bcs=d\&nselm=h\&m et_y=en_atm_co2e_pc\&scale_y=lin\&ind_y=false\&rdim=country\&idim=country:TUR\&ifdim $=$ country\&hl=tr\&d $1=$ tr\&ind=false $>$ [Accessed April 29, 2020].

Ying Chen (2019) Renewable energy investment and employment in China, International Review of Applied Economics, 33:3, 314-334, doi: 10.1080/02692171.2018.1513458.

Yuksel, I. (2012). Water Development For Hydroelectric in Southeastern Anatolia Project (GAP) in Turkey. Renewable energy, 39 (1), 17-23. doi: https://doi.org/10.1016/j.renene.2011.08.006.

Zwaan, Van der B., Cameron, L., \& Kober, T. (2013). Potential for renewable energy jobs in the Middle East. Energy Policy, 60, 296-304. doi: https://doi.org/10.1016/j.enpol.2013.05.014. 